\section{Jurnal Mitra Pendidikan (JMP Online)}

URL : http://e-jurnalmitrapendidikan.com
JMP Online

Vol. 4, No. 12, 836-849.

(C) 2020 Kresna BIP. e-ISSN 2550-0481 p-ISSN 2614-7254

\title{
BERMAIN MAKAH-MAKAH STRATEGI PEMBELAJARAN \\ DALAM MENINGKATKAN HASIL BELAJAR SISWA \\ PADA PELAJARAN SOSIOLOGI DI SMA NEGERI 1 LANGSA KOTA LANGSA
}

\author{
Safrizal \\ SMA Negeri 1 Langsa
}

INFORMASI ARTIKEL

Dikirim : 20 Desember 2020

Revisi pertama : 23 Desember 2020

Diterima : 29 Desember 2020

Tersedia online : 09 Januari 2021

Kata Kunci: Makah Makah, Hasil Belajar, Sosiologi

Email: safrizalkamaruddin@gmail.com
ABSTRAK

Penelitian ini bertujuan untuk meningkatkan hasil belajar siswa Kelas X-IPA8 pada pelajaran sosiologi di SMA negeri 1 Langsa, mengingat rendahnya hasil belajar siswa pada palajaran sosiologi penulis menggunakan permainan Makah-makah dalam meningkatkan hasil belajar siswa. Dari hasil kegiatan pembelajaran yang telah dilakukan dan berdasarkan pembahasan serta analisis yang telah dilakukan dapat disimpulkan bahwa bermaian makah-makah dalam pembelajaran sosiologi memiliki dampak positif yaitu dapat meningkatkan hasil belajar siswa yang ditandai dengan peningkatan ketuntasan belajar siswa dan keaktifan siswa dalam pembelajarn sosiologi. Sebelum menggunakan permaian makah-makah dalam pembelajaran sosisologi pada kompetensi sosiologi sebagai ilmu yang mengkaji hubungan masyarakat dan lingkungan hanya 10 siswa yang tuntas atau $27 \%$ dan sesudah di terapkan permaian sosiologi siswa meningkat sampai 94\%. Maka dapat disimpulkan adanya peningkatan hasil belajar siswa pada kompetensi sosiologi sebagai ilmu yang mengkaji hubungan masyarakat dan lingkungan melalui permaiana makahmakah pada siswa kelas X IPA-8 SMAN 1 Langsa tahun pelajaran 2019/2020. 


\section{PENDAHULUAN \\ Latar Belakang}

Tujuan pengajaran sosiologi di Sekolah Menengah pada dasarnya mencakup dua sasaran yang bersifat kognitif dan bersifat praktis. Secara kognitif pengajaran Sosiologi dimaksudkan untuk memberikan pengetahuan dasar Sosiologi agar siswa mampu memahami dan menelaah secara rasional komponenkomponen dari individu, kebudayaan dan masyarakat sebagai suatu sistem. Sementara itu sasaran yang bersifat praktis dimaksudkan untuk mengembangkan keterampilan sikap dan perilaku siswa yang rasional dan kritis dalam menghadapi kemajemukan masyarakat, kebudayaan, situasi sosial serta berbagai masalah sosial yang ditemukan dalam kehidupan sehari-hari. (Departemen Pendidikan Nasional, 2003:8). Tujuan pendidikan nasional ini sangat luas dan bersifat umum sehingga perlu dijabarkan dalam Tujuan Institusional yang disesuaikan dengan jenis dan tingkatan sekolah yang kemudian dijabarkan lagi menjadi tujuan kurikuler yang merupakan tujuan kurikulum sekolah yang diperinci menurut bidang studi/mata pelajaran atau kelompok mata pelajaran. Tujuan instruksional dijabarkan menjadi Tujuan Pembelajaran Umum dan kemudian dijabarkan lagi menjadi Tujuan Pembelajaran Khusus (TPK).

Kenyataan dilapangan Dalam mencapai Tujuan Pembelajaran Khusus pelajaran sosiologi di SMA Negeri 1 Langsa kelas X-8 jauh dari harapan. Hal ini terlihat dari masih rendahnya nilai yang diperoleh siswa pada kompetensi sosiologi sebagai ilmu yang mengkaji hubungan masyarakat dan lingkungan yaitu hanya 10 siswa yang tuntas dari 37 keseluruhan siswa.

Situasi seperti itu selalu terulang dari topik yang satu ke topik yang lain. Untuk mengantisipasinya, guru biasanya memberikan pekerjaan rumah sebagai latihan tambahan. Guru berharap siswa lebih banyak melatih dirinya di rumah, agar tidak tertinggal oleh temannya yang lain. Tidak jarang tugas diberikan secara berkelompok dan individu. Namun hasilnya selalu belum memuaskan. Setelah memperhatikan situasi kelas yang seperti itu, maka perlu dipikirkan cara penyajian dan suasana pembelajaran sosiologi yang cocok buat siswa, sehingga siswa dapat berpartisipasi aktif dalam proses pembelajaran.

Untuk mengatasi permasalahan tersebut perlu dicari langkah-langkah yang tepat dan tehnik-tehnik yang sesuai. Langkah-langkah tepat itu merupakan pengetahuan dan ketrampilan yang sebaiknya dimiliki siswa sehingga walaupun tidak dengan cepat siswa menemukan jawaban suatu persoalan tetapi paling tidak mereka menemukan solusi lain untuk mengatasinya. Pengetahuan dan ketrampilan untuk menemukan solusi dapat di peroleh siswa dengan membiasakan diri bekerja dengan langkah-langkah yang terstruktur. Disamping itu perlu diupayakan agar siswa menyenangi pelajaran sosiologi khususnya pada materi yang banyak teorinya sehingga sangat membosankan melalui sebuah permainan makah-makah dengan media pembelajaran yang disukai siswa.

Makah-makah adalah salah satu jenis permainan tradisional yang berasal dari provinsi Aceh. Permainan ini sangat mudah dimainkan dan tidak memerlukan peralatan yang rumit. Makah-makah merupakan permainan tradisional berjenis kompetisi dan dilakukan secara kolektif, dimana para peserta dibagi menjadi dua atau 4 regu yang saling bertanding. Penerapan bermain Makah-Makah 
memungkinkan setiap siswa dapat lebih semangat dan tertarik akan mata pelajaran sosiologi yang sehingga dapat mempengaruhi hasil belajar siswa.

Berdasarkan latar belakang tersebut maka guru mengharapkan setelah proses belajar mengajar sosiologi dengan bermain makah-makah dapat meningkatkan hasil belajar siswa khususnya pada kompetensi sosiologi sebagai ilmu yang mengkaji hubungan masyarakat dan lingkungan

\section{Rumusan Masalah}

Berdasarkan latar belakang di atas maka dapat dibuat rumusan masalah yaitu apakah bermain makah-makah dapat meningkatkan hasil belajar sosiologi pada kelas X.8 SMAN 1 Langsa tahun pelajaran 2019/2020 ?.

\section{Tujuan Penelitian}

Tujuan yang diharapkan dari penelitian ini adalah untuk meningkatkan hasil belajar sisiwa pada kompetensi sosiologi sebagai ilmu yang mengkaji hubungan masyarakat dan lingkungan pada siswa kelas X-8 SMA Negeri 1 Langsa.

\section{Manfaat Penelitian}

Adapun manfaat penelitian ini adalah :

1. Bagi siswa, dapat meningkatkan hasil belajar sosiologi, khususnya pada kompetensi sosiologi sebagai ilmu yang mengkaji hubungan masyarakat dan lingkungan.

2. Bagi guru, dapat mengetahui bahwa dengan menggunkaan permainan tradisional khususnya permainan makah-makah dapat memperbaiki dan meningkatkan prestasi belajar siswa di kelas.

3. Bagi sekolah, dapat memberikan sumbangan yang baik pada sekolah dalam rangka meningkatkan kualitas mutu pendidikan di sekolah.

\section{KAJIAN PUSTAKA \\ Pengertian Belajar}

Belajar menurut Djamarah (2014:11) proses perubahan prilaku berkat pengalaman dan latihan. Artinya tujuan kegiatan adalah perubahan tingkah laku, yang menyangkut pengetahuan, keterampilan maupun sikap, bahkan meliputi segenap aspek organisme atau pribadi. Menurut Sardiman (2009:20), yang mengatakan bahwa belajar mempunyai dua arti yaitu arti luar dan arti terbatas/khusus. Dalam pengertian luas, belajar dapat diartikan sebagai kegiatan psiko-fisik menuju ke perkembangan pribadi seutuhnya. Kemudian dalam arti sempit, belajar dimaksudkan sebagai usaha penguasaan materi ilmu pengetahuan yang merupakan sebagian kegiatan menuju terbentuknya kepribadian seutuhnya. Relevan dengan ini, ada pengertian bahwa belajar adalah penambahan pengetahuan. Definisi konsep ini dalam praktiknya banyak dianut di sekolahsekolah.

Selanjutnya Aunurrhaman (2016:35) mengemukakan bahwa belajar adalah suatu usaha sadar yang dilakukan oleh individu dalam perubahan tingkah laku baik melalui latihan dan pengalaman yang menyangkut aspek kognitif, afektif, dan 
psikomotorik untuk memperoleh tujuan tertentu. Sedangkan menurut Gagne mengemukakan bahwa, belajar adalah perubahan disposisi atau kemampuan yang dicapai seseorang melalui aktivitas. Perubahan disposisi tersebut bukan diperoleh langsung dari proses pertumbuhan seseorang secara ilmiah (Suprijono,2013:2).

Dari kedua pendapat ahli di atas, maka dapat disimpulkan bahwa belajar merupakan proses perubahan prilaku yang dialami siswa melalui interaksi edukatif yang bermakna dimana siswa memperoleh pengetahuan dan keterampilannya melalui pengalaman dan interaksi langsung dengan alam dan lingkungan sekitarnya sebagai sumber pembelajaran.

\section{Pengertian Hasil Belajar}

Suprijono (2013:2) mengemukakan bahwa belajar adalah perubahan disposisi atau kemampuan yang dicapai seseorang melalui aktivitas. Perubahan disposisi tersebut bukan diperoleh langsung dari proses pertumbuhan seseorang secara alamiah. Hasil belajar adalah pola-pola perbuatan, nilai-nilai, pengertianpengertian, sikap-sikap, apresiasi dan keterampilan. Merujuk pemikiran Gagne, hasil belajar berupa informasi verbal, keterampilan intelektual, strategi kognitif, keterampilan motorik, dan sikap.

\section{Permainan Makah-Makah}

Makah-makah adalah salah satu jenis permainan tradisional yang berasal dari provinsi Aceh. Permainan ini sangat mudah dimainkan dan tidak memerlukan peralatan yang rumit. Makah-makah merupakan permainan tradisional berjenis kompetisi dan dilakukan secara kolektif, dimana para peserta dibagi menjadi dua atau 4 regu yang saling bertanding.

Nama permainan tradisional makah-makah merujuk pada kata "Makkah" atau Mekah". Pemakaian kata "Makkah" atau Mekah" dapat diartikan maknai dengan dua arti. Pertama, "Makkah" atau Mekah" dapat diartikan sebagai pusat atau kiblat bagi segenap umat Islam di seluruh dunia. Pemaknaan ini merujuk pada inti dari permainan makah-makah, dimana kedua regu yang terlibat dalam permainan ini berlomba lomba untuk dapat mencapai titik sasaran atau yang dinamakan dengan makkah (Sufi, 2004:27). Titik sasaran atau Makkah dapat dimaknai sebagai simbol dari pusat atau kiblat umat Islam di seluruh dunia, termaksut provinsi Aceh yang mayoritas penduduknya adalah Muslim, di mana setiap orang Islam berlomba-lomba untuk dapat sampai ke rumah Tuhan atau mekah, misalnya dengan maksut untuk menunaikan ibadah haji atau umrah.

Makna "Makkah" atau Mekah" yang kedua adalah bahwa Provinsi Aceh sebagai daerah yang mendapatkan julukan sebagai Serambi Mekah. Serambi sendiri dapat diartikan sebagai bagian depan dari rumah. Jadi, untuk dapat sampai ke mekah, maka harus dilalui terlebih dulu serambinya atau "beranda depan"nya. (http://achehlibrary.com).

\section{Peralatan}

Peralatan yang diperlukan dalam memainkan makah-makah sangat mudah diperoleh di lingkungan sekitar tempat tinggil kita. Makah-makah hanya memerlukan sebiji batu atau benda lain yang berukuran kecil agar mudah di sembunyikan dalam genggaman tangan yang diletakkan dibelakang punggung 
peserta pemain atau siswa. Dalam hal ini guru menambahkan materi pelajaran dan soal dalam lipatan kertas yang disebut bunga ilmu dalam permainan makah-makah agar lebih menarik.

2. Aturan Permainan

Sufi (2004:30) menerangkan bahwa terdapat beberapa aturan yang berlaku dalam permaian Makah-Makah. Aturan-aturan tersebut sebagai berikut:

a. Jumlah peserta yang dibagi menjadi dua regu. Masing masing regu berjumlah paling sedikit 4 (empat) siswa atau lebih, tergantung dari jumlah total peserta yang akan mengikuti permainan ini.

b. Masing masing regu dipimpin oleh ketua regu

c. Masing masing regu berlomba-lomba untuk dapat sampai terlebih dulu ke titik sasaran atau yang disebut sebagai makkah.

d. Proses kompetisi antar kedua regu untuk sampai ke titik sasaran dilakukan dengan cara-cara yang akan di jelaskan dalam poin "cara bermain".

e. Regu yang pertama sampai ke titik sasaran keluar sebagai pemenang (Sufi, 2004:27)

3. Cara Bermain

Masing-masing regu saling berhadapan satu sama lain dengan jarak pemisah sekitar dua meter. Tepat di bagian tengah jarak pemisah tersebut diberi pertanda, bisa digambar sebuah titik atau menuliskan tanda garis lurus. Pembuatan tanda harus benar-benar pada posisi yang adil, artinya benar-benar dibuat pada bagian tengah antar regu. Tidak boleh berbeda, misalnya terlalu dekat atau terlalu jauh dengan salah satu regu.

Jika sudah selesai. Maka langkah selanjutnya adalah masing-masing ketua regu meletakkan batu yang sudah dipegang untuk diberikan kepada anggota regunya. Peletakan batu harus dilakukan dengan hati-hati jangan sampai diketahui oleh regu lawan. Oleh karenanya, selain ketua regu harus pintar mengecoh lawan, di sini para anggota juga harus pandai berpura-pura dengan seolah-olah batu yang dipegang ketua regu diberikan kepadanya. Padahal dari semua anggota regu hanya satu orang anggota saja yang mendapatkan batu tersebut.

Bila batu sudah diletakkan, sekarang tugas ketua regu adalah menggunakan insting yang tajam untuk bisa menebak keberadaan peletakan batu pada regu lawan. Misalnya telah ditentukan regu mana yang akan menebak duluan, regu A misalnya. Maka, ketua dari regu A akan mencoba menebak keberadaan batu yang berada di masing-masing anggota regu B.

Apabila tebakan ketua regu A benar maka diberi poin 50 dan hanya perlu menjawab satu soal, apabila soalnya bisa dijawab maka regu A mendapat poin 50 lagi dan regu A boleh untuk berpindah satu langkah ke depan. Dengan begitu regu A bisa semakin lebih dekat ke titik tujuan. Sebaliknya apabila tebakan regu A ternyata salah, maka harus menjawab dua soal untuk bisa maju satu langkang kedepan. Untuk bisa maju satu langkah kedepan harus memiliki poin 100. Begitu Seterusnya. Puncaknya, regu mana yang berhasil sampai duluan ke titik tujuan tadi, maka dialah yang akan menjadi pemenangnya. 


\section{Nilai Budaya}

Permainan tradisional dapat memacu perkembangan jiwa dan raga seseorang, dengan memainkan permainan tradisional, anak-anak dapat mengembangkan fantasi, daya imajinasi, dan kreatifitasnya. Selain itu banyak nilai penting pada permainan tradisional, antara lain sosialisasi, rangsangan kreativitas, sarana belajar, penyaluran energi emosional, perkembangan moral, fisik dan kepribadian (Elisabeth B. Hurlok, 1992).

Terdapat cukup banyak nilai budaya, baik yang bersifat fisik maupun pesan moral yang dapat di perolah pada permainan Makah-Makah. Nilai-nilai tersebut adalah sebagai berikut :

a. Kekompakan : Permainan ini mengajarkan kekompakan pada masingmasing anggota dan dengan ketua regu. yaitu untuk bisa menciptakan kesepahaman dan saling pengertian antar ketua dengan anggota, bisa dilihat dalam hal peletakan batu sampai penebakan batu regu lawan.

b. Kepemimpinan : Khususnya bagi yang terpilih sebagai ketua regu, permainan ini melatih untuk menumbuhkan jiwa kepemimpinan sekaligus kedewasaan berpikir. Bagaimana ketua regu harus bisa menyatukan pendapat dan mengambil sebuah keputusan yang mampu memberikan hasil yang baik.

c. Kepercayaan : Ketua regu dan para anggota harus saling percaya satu sama lain merupakan kunci dari permainan ini. Tanpa nilai kepercayaan bisa dipastikan penampilan regu ini tidak akan maksimal. Karena pasti akan ada orang yang tidak menjalankan amanatnya dengan baik.

\section{METODE PENELITIAN}

\section{Waktu, Tempat dan Subjek Penelitian}

Penelitian ini akan dilaksanakan di SMA Negeri 1 Langsa Kota Langsa, dilaksanakan pada semester genap tahun ajaran 2019/2020. Subjek dalam penelitian ini adalah siswa kelas X-8 SMA Negeri 1 Langsa sebanyak 37 orang, dengan rincian laki-laki sebanyak 17 orang dan perempuan sebanyak 20 orang.

\section{Jenis Penelitian}

Penelitian ini menggunakan desain atau rancangan Penelitian Tindakan (Action Research), dan Penelitian Lapangan (Field Reseacch), dalam dua siklus. Hal ini dilakukan untuk melihat sejauhmana perbandingan hasil dari kedua objek tersebut.

\section{Prosedur Penelitian Tindakan Kelas}

Prosedur penelitian tindakan kelas dapat dilaksanakan melalui empat langkah utama yaitu perencanaan, tindakan, observasi, dan refleksi. Empat langkah utama yang saling berkaitan itu dalam pelaksanaan penelitian tindakan kelas sering disebut dengan istilah satu siklus, yaitu Perencanaan, Implementasi tindakan, Observasi, dan Refleksi. 


\section{Teknik Pengumpulan Data}

Instrumen atau alat-alat dan teknik pemantauan atau monitoring dalam proses pengumpulan data antara lain observasi, pemberian kuisioner, dan soal untuk tes agar mendapatkan hasil belajar yang konkrit.

\section{Teknik Analisis Data}

Pada bagian teknik analisis data ini, penulis memberikan gambaran perbandingan antara siklus I dan II dan dipaparkan dalam bentuk tabel dan grafik. Hal ini dilakukan, agar hasil pada siklus I dan II, terlihat lebih sempurna. Selain itu, penulis juga melengkapi dengan dokumentasi selama proses penelitian ini berlangsung. Data dikumpulkan, kemudian dipetakan dan dianalisis bersama mitra kolaborasi sejak penelitian tindakan dimulai. Selanjutnya data dikembangkan selama proses refleksi sampai proses penyusunan laporan. Teknis analisis data yang digunakan adalah model alur, yaitu reduksi data, penyajian data, dan penarikan kesimpulan (Sugiyono, 2016).

\section{Instrumen Penelitian}

Untuk mendapatkan data penelitian yang valid dan dapat dipertangungjawabkan, maka dalam dalam penelitian ini digunakan beberapa instrumen pembantu, yaitu lembar observasi, dan lembar hasil tes siswa.

\section{Indikator Keberhasilan} ini apabila:

Sedangkan untuk mengetahui tingkat keberhasilan penelitian tindakan

1. Meningkatnya hasil belajar Sosiologi kompetensi sosiologi sebagai ilmu yang mengkaji hubungan masyarakat dan lingkungan ditandai rata-rata nilai yang dicapai diatas KKM 75 sebanyak $75 \%$ dari jumlah peserta didik.

2. Adanya peningkatan keaktifan belajar peserta didik pada kategori sangat aktif dan aktif yang mencapai $85 \%$.

\section{HASIL PENELITIAN DAN PEMBAHASAN \\ Hasil Penelitian \\ Deskripsi Data Sebelum Tindakan}

Peneliti melakukan tes awal/prasiklus pada hari selasa, 16 Maret 2020 dengan mengadakan tes awal terhadap 37 anak. Materi tes awal dilakkan pada kompetensi sosiologi sebagai ilmu yang mengkaji hubungan masyarakat dan lingkungan dengan materi hakikat sosiologi. Pada tes awal ini peneliti tidak menggunakan media atau permainan makah-makah, melainkan hanya menggunakan lembaran soal. Tujuan diadakan tes ini adalah untuk mengetahui sejauh mana hasil belajar siswa.

Hasil belajar yang di peroleh siswa sangat rendah, banyak siswa yang mendapat nilai di atas KKM yaitu 75 artinya hanya 10 siswa yang tuntas dari 37 siswa demikian juga dengan keaktifan siswa dalam proses pembelajaran sosiologi pada kompetensi yang sama mencapai $62 \%$ siswa yang aktif atau 23 siswa yang aktif dari 37 siswa. 
Untuk lebih jelas dapat di lihat pada tabel keaktifan siswa dan tabel hasil belajar siswa pra siklus.

Tabel 1. Keaktifan Siswa Pra Siklus

\begin{tabular}{|c|c|c|c|}
\hline No & Siswa Aktif & Siswa Keseluruhan & Persentase \\
\hline 1 & 23 & 37 & $62 \%$ \\
\hline
\end{tabular}

Sumber : Hasil Penelitian, diolah (2020)

Tabel 2. Hasil Belajar Siswa Pra Siklus

\begin{tabular}{|c|c|c|c|}
\hline \multirow{2}{*}{ No } & \multirow{2}{*}{ Ketuntasan } & \multicolumn{2}{|c|}{ Jumlah Siswa } \\
\cline { 3 - 4 } & & Jumlah & Persen \\
\hline 1 & Tuntas & 10 & 27 \\
\hline 2 & Belum tuntas & 27 & 73 \\
\hline & Jumlah & 37 & 100 \\
\hline
\end{tabular}

Sumber : Hasil Penelitian, diolah (2020)

Berdasarkan hasil belajar pra siklus, diputuskan untuk menerapkan permainan makah-makah dalam upaya meningkatkan hasil belajar sosiologi pada kompetensi sosiologi sebagai ilmu yang mengkaji hubungan masyarakat dan lingkungan di kelas X.8 SMA Negeri 1 Langsa. Mengingat kompetensi tersebut masih penuh dengan teori dan membosankan dan pengalaman peneliti ketika mengajar sosiologi banyak siswa yang merasa bosan dengan kompetensi tersebut. Sehingga peneliti menerepkan permainan makah-makah agar hasil belajar dan keaktifan siswa meningkat dalam pelajaran sosiologi.

\section{Siklus I}

\section{Perencanaan Tindakan I}

Perencanaan tindakan pembelajaran dikembangkan berdasarkan hasil studi pendahuluan. Peneliti menyusun rencana pembelajaran dengan menggunakan permainan makah-makah untuk meningkatkan hasil belajar sosiologi pada kompetensi sosiologi sebagai ilmu yang mengkaji hubungan masyarakat dan lingkungan.

Rencana pembelajaran ini digunakan sebagai petunjuk dan pegangan guru mengenai langkah yang harus dilakukan agar pelaksanaan pembelajaran berjalan dengan efektif dan efisien. Dalam rencana pembelajaran mengenai kompetensi dasar yang harus dicapai, indikator pembelajaran, materi / tema masalah, alokasi waktu dan jenis evaluasi untuk memperoleh umpan balik.

Pada siklus I ini kegiatan yang direncanakan untuk dilaksanakan adalah:

a. Menyiapkan rencana pembelajaran dengan langkah-langkah penyiapan materi yang terstruktur.

b. Menyiapkan materi tentang Hakikat sosiologi, Sosiologi sebagai ilmu pengetahuan, Sejarah Perkembangan sosiologi dan kedudukan sosiologi di antara ilmu-ilmu lain

c. Permainan makah-makah yang dirancang oleh guru dan lipatan kertas origami (bunga ilmu) dibuat oleh siswa. 
d. Menyiapkan lembar observasi untuk melihat situasi belajar ketika pembelajaran dengan permainan mekah mekah dengan media "bunga ilmu dari kertas origami" berlangsung.

e. Menyiapkan lembar evaluasi.

2. Tahap Pelaksanaan Tindakan

Pada tahap ini, guru melaksanakan tindakan sesuai dengan perencanaan yang telah dirumuskan. Melakukan pengamatan terhadap tindakan pembelajaran secara sistematis. Pengamatan dilakukan secara terus-menerus oleh peneliti untuk memantau dan merekam gejala-gejala yang muncul baik yang sifatnya mendukung atau menghambat proses pembelajaran.

Pelaksanaan tindakan pertama dilaksanakan pada tanggal 26 April 2020 dengan alokasi waktu $2 \times 45$ menit.

a. Pendahulaun

1) Guru mengorganisasikan siswa ke dalam kelompok-kelompok heterogen beranggotakan 4 orang, dan dipimpin oleh seorng ketua kelompok. Kemampuan guru dalam mengorganisasikan siswa masih perlu perbaikan.

2) Guru memotivasi peserta didik dengan memberi penjelasan tentang pentingnya mempelajari materi ini. Dan guru memulai pelajaran dengan menanyakan kepada siswa tentang sejarah sosiologi dan pengertian sosiologi. Sebagian besar siswa dapat menjawab pertanyaan guru, tetapi tidak secara bersama-sama. Sedangkan siswa yang berani mengemukakan pendapat sendiri hanya 4 orang orang.

3) Guru menayakan tentang permainan makah-makah kepada siswa, apakah merakah pernah bermaian makah-makah. siswa tidak pernah mendengarkan permianan makah-makah. guru menjelaskan tata cara bermaian makah-makah. bahwa permainan makah-makah merupakan yang bersifat kompetisi dan kelompok yang sudah di bagikan guru akan bertanding. masing masing Ketua kelompok menarik undian yang telah dibuat oleh guru. Hasil undiannya kelompok 1 bertanding dengan kelompok 2, kelompok 3 bertanding dengan kelompok 4. Lalu guru menjelaskan kelompok yang keluar sebagai pemenang akan saling bertanding untuk merebutkan juara I

b. Kegiatan Inti

1) Siswa berdiri sesuai dengan kelompok yang telah dibagi lalu ketua regu menyiapkan anggotanya. Guru membagikan lipatan kertas origami yang diberi nama bunga ilmu dan meberikan batu kepada masing masing ketua regu.

2) Siswa melaksanakan permaian dengan antusias (Ternyata pada pertemuan ini masih ada beberapa siswa yang tidak bermaian secara sepenuhnya.. Mereka masih asik menceritakan bercerita dan bercanda. Bahkan ada diantara mereka yang melakukan perilaku tidak relevan, seperti menganggu teman temannya, mengejek teman nya. Melihat kejadian tersebut guru mengingatkan kembali bahwa mereka harus bermaian seperti peraturan yang telah dijelaskan oleh 
guru. Guru menjalaskan kembali fungsi utama ketua regu adalah menyiapkan anggota agar bermain sesuai dengan peraturan.

3) Masing masing kelompok saling menebak/menjawab soal yang di berikan oleh kelompok lawan melalui kertas origami. Guru perlu menambahkan lagi lipatan kertas soal origami supaya lebih bervariasi dalam pemilihan soal.

c. Penutup

1) Bersama dengan siswa, guru membahas hasil kerja siswa dan dilanjutkan dengan menghitung skor yang diperoleh tiap kelompok.

2) Memberikan penghargaan kepada anggota kelompok yang mendapat skor paling tinggi, dan kepada siswa yang paling berpartisipasi.

3) Membuat rangkuman tentang pembelajaran hari itu, Waktu menyimpulkan hasil pembelajaran ada beberapa siswa yang berani menyimpulkan tentang materi yang telah disampaikan.

4) Menginformasikan materi yang akan dibahas pada pertemuan berikutnya.

\section{Hasil Pengamatan (Observasi)}

Observasi dilaksanakan pada kegiatan tatap muka, observasi dilakukan oleh observer yaitu teman sejawat pada SMAN 1 Langsa. Observasi dilakukan untuk mengetahui keaktifan siswa, kerja sama, kecepatan, dan ketepatan siswa dalam memahami kompetensi yang diuji. Hasil observasi digunakan sebagai bahan refleksi dan untuk merencanakan rencana tindakan pada siklus II.

Adapun hasil yang perolehan nilai masing masing kelompok dapat di lihat pada tabel di bawah ini. Nilai hasil belajar pada Siklus I dapat di dilihat pada tabel di bawah ini :

Tabel 3. Perolehan Nilai Kelompok Siklus I

\begin{tabular}{|c|c|c|c|c|}
\hline No & $\begin{array}{c}\text { Nama } \\
\text { Kelompok }\end{array}$ & $\begin{array}{c}\text { Nilai Babak } \\
\text { Pertama }\end{array}$ & $\begin{array}{c}\text { Nilai Babak } \\
\text { ke dua }\end{array}$ & Juara \\
\hline 1 & Kelompok 1 & 800 & 750 & 2 \\
\hline 2 & Kelompok 2 & 650 & - & 3 \\
\hline 3 & Kelompok 3 & 800 & 800 & 1 \\
\hline 4 & Kelompok 4 & 600 & - & 4 \\
\hline
\end{tabular}

Sumber : Hasil Penelitian, diolah (2020)

Dari tabel diatas menunjukan pemenangnya kelompok 3 dengan perolahan nilai 800 dan juara kedua kelompok 1 dengan jumlah nilai 750. Dan ditemukan dengan keaktifan siswa mencapai $81 \%$ ini menunjukkan adanya peningkatan keaktifan siswa dalam proses belajar mengajar dalam permainan makah-makah. Seperti yang tertera pada tabel di bawah ini

Tabel 4. Keaktifan Siswa Siklus I

\begin{tabular}{|l|l|l|l|}
\hline No & Siswa aktif & Siswa keseluruhan & Persentase \\
\hline 1 & 30 & 37 & $81, \%$ \\
\hline
\end{tabular}

Sumber : Hasil Penelitian, diolah (2020) 


\section{Refleksi}

Berdasarkan hasil test kemampuan siswa siklus I dapat dijabarkan halhal sebagai berikut :

a. Pada siklus I diperoleh 20 siswa (54\%) tuntas dan 17 siswa (46\%) tidak tuntas

Tabel 5. Hasil Belajar Siswa Siklus I

\begin{tabular}{|c|c|c|c|}
\hline \multirow{2}{*}{ No } & \multirow{2}{*}{ Ketuntasan } & \multicolumn{2}{|c|}{ Jumlah siswa } \\
\cline { 3 - 4 } & & Jumlah & Persen \\
\hline 1 & Tuntas & 20 & $54 \%$ \\
\hline 2 & Belum tuntas & 17 & $46, \%$ \\
\hline & Jumlah & 37 & 100 \\
\hline
\end{tabular}

Sumber : Hasil Penelitian, diolah (2020)

b. Nilai yang diperoleh sudah ada peningkatan tetapi masih belum sesuai dengan keinginan. Hal ini terjadi karena siswa masih belum optimal dalam bekerja sama namun aktivitas siswa sudah mulai membaik pada Siklus I.

c. Karena keaktifan dan hasil belajar siswa sudah baik dari pra siklus, maka perangkat pembelajaran dan instrumen yang digunakan pada siklus II tetap sama seperti di siklus I.

\section{Siklus II}

Sesuai dengan pelaksanaan dan hasil refleksi I, peneliti perlu menindaklanjuti pelaksanaannya pada siklus II dengan tahapan yang sama seperti siklus I. Adapun uraian pelaksanaan siklus II akan peneliti paparkan sebagai berikut:

1. Persiapan

Persiapan dilakukan dengan menyiapkan media pembelajaran menggunakan lipatan kertas origami berupa bunga ilmu. Tidak lupa diberikan tugas yang harus mereka kerjakan dalam lipatan kertas origami. Dalam kesempatan ini sudah disiapkan format untuk menuliskan pemenang dan juga soal-soal latihan dalam lipatan origami.

2. Pelaksanaan Tindakan Siklus II

Tahap ini merupakan pelaksanaan dari rancangan yang sudah didesain mengikuti pola permainan makah-makah dengan skenario yang sama pada siklus I. Pada siklus ke dua ini guru lebih tegas kepad siswa yang tidak mengikuti proses pembelajaran dan juga memberi soal dalam lipatan kertas origami lebih berfariasi. Pada siklus ini walau mereka bekerja dengan kelompok masing-masing. Dalam hal ini terlihat secara langsung situasi belajar yang aktif, kreatif, antusias siswa dalam belajar, hampir seluruh kelompok mampu menguasai dan aktif dalam proses pembelajaran tersebut.

3. Hasil Pengamatan (Observasi)

Pelaksanaan observasi pada kegiatan siklus II sama dengan kegiatan pada siklus I. Dalam hal ini observasi dilakukan oleh teman sejawat yaitu guru sebagai observer. Observasi dilakukan untuk mengetahui keaktifan siswa dalam memahami mengikuti proses pembelajaran sosiologi pada kompetensi yang sama dengan materi berbeda. Adapun hasil belajar dan keaktifan siswa yang di peroleh siklus II dapat dilihat pada tabel di bawah ini : 
Tabel 6. Nilai Hasil Belajar Siklus II

\begin{tabular}{|c|c|c|c|}
\hline \multirow{2}{*}{ No } & \multirow{2}{*}{ Ketuntasan } & \multicolumn{2}{|c|}{ Jumlah siswa } \\
\cline { 3 - 4 } & & Jumlah & Persen \\
\hline 1 & Tuntas & 35 & 94,59 \\
\hline 2 & Belum tuntas & 2 & 5,41 \\
\hline \multicolumn{2}{|c|}{ Jumlah } & 37 & 100 \\
\hline
\end{tabular}

Sumber : Hasil Penelitian, diolah (2020)

Tabel 7. Keaktifan Siswa Siklus II

\begin{tabular}{|c|c|c|c|}
\hline No & Siswa aktif & Siswa keseluruhan & Persentase \\
\hline 1 & 34 & 37 & $92 \%$ \\
\hline
\end{tabular}

Sumber : Hasil Penelitian, diolah (2020) bawah ini :

Nilai hasil belajar kelompok pada Siklus II dapat di dilihat pada tabel di Tabel 8. Perolehan Nilai Kelompok Siklus I

\begin{tabular}{|l|l|l|l|l|}
\hline No & $\begin{array}{l}\text { Nama } \\
\text { Kelompok }\end{array}$ & $\begin{array}{l}\text { Nilai babak } \\
\text { pertama }\end{array}$ & $\begin{array}{l}\text { Nilai Babak } \\
\text { ke dua }\end{array}$ & Juara \\
\hline 1 & Kelompok 1 & 800 & 750 & 2 \\
\hline 2 & Kelompok 2 & 750 & - & 3 \\
\hline 3 & Kelompok 3 & 800 & 800 & 1 \\
\hline 4 & Kelompok 4 & 750 & - & 4 \\
\hline
\end{tabular}

Sumber : Hasil Penelitian, diolah (2020)

Dari tabel diatas menunjukan pemenangnya masih kelompok 3 dengan perolahan nilai 800 dan juara kedua juga masih kelompok 1 dengan jumlah nilai 750.

\section{Refleksi}

Berdasarkan hasil test kemampuan siswa siklus II dapat dilihat, Dari tabel di atas menunjukan siswa yang tuntas pada siklus ke I berjumlah 35 siswa atau 94\% dari 37 siswa. Demikian juga dengan keaktifan siswa di peroleh 92\% yang aktif atau 34 siswa yang aktif dari 37 siswa secara keseluruhan.

\section{Pembahasan}

Berdasarkan hasil hasil belajar dan keaktifan siswa dalam pelajaran sosiologi kompetensi sosiologi sebagai ilmu yang mengkaji hubungan masyarakat dan lingkungan siswa mengalami peningkatan baik hasil belajar maupun kektifan siswa dari pra siklus, siklus I dan siklus ke II.

Pada pra siklus peneliti belum menggunakan permainan makah-makah dalam pembelajaran sosiologi pada kompetensi sosiologi sebagai ilmu yang mengkaji hubungan masyarakat dan lingkungan sehingga hasil belajar dan keaktifan siswa masih sangat rendah artinya masih di bawah KKM (75), 10 siswa yang tuntas dan 27 siswa masih belum tuntas dan keaktifan siswa mencapai $62 \%$ siswa yang aktif atau 23 siswa yang aktif dari 37 siswa. 
Pada siklus 1 siswa sudah mulai aktif dan hasil belajar sudah mulai meningkat, siswa yang tuntas mencapai 20 siswa dan 17 siswa masih di bawah KKM Sedangkan untuk keaktifan siswa mencapai 31 siswa atau $81 \%$ dari 37 siswa. Pada siklus II juga mengalami peningkatan baik dari hasil belajar maupun keaktifan siswa. Siswa yang aktif mencapai $92 \%$ atau 34 aktif dan siswa yang tuntas mencapai 35 siswa atau 94\%.

Maka dapat di simpulakan bahwa bermain makah-makah sangat berpengaruh terhadap peningkatan hasil belajar siswa kelas X-8 SMAN 1 Langsa tahun pelajaran 2019/2020. Peningkatan hasil belajar terjadi karena guru mengunkan permainan makah-mkaah dan lipatan kertas origami sebagai pembelajaran sosiologi.

\section{KESIMPULAN DAN SARAN \\ Kesimpulan}

Dari hasil kegiatan pembelajaran yang telah dilakukan dan berdasarkan pembahasan serta analisis yang telah dilakukan dapat disimpulkan bahwa bermaian makah-makah dalam pembelajaran sosiologi memiliki dampak positif yaitu dapat meningkatkan hasil belajar siswa yang ditandai dengan peningkatan ketuntasan belajar siswa dan keaktifan siswa dalam pembelajarn sosiologi. Sebelum menggunakan permaian makah-makah dalam pembelajaran sosisologi pada kompetensi sosiologi sebagai ilmu yang mengkaji hubungan masyarakat dan lingkungan hanya 10 siswa yang tuntas atau $27 \%$ dan sesudah di terapkan permaian sosiologi siswa meningkat sampai 94\%. Maka dapat disimpulkan adanya peningkatan hasil belajar siswa pada kompetensi sosiologi sebagai ilmu yang mengkaji hubungan masyarakat dan lingkungan melalui permaiana makah-makah pada siswa kelas X-8 SMAN 1 Langsa tahun pelajaran 2019/2020.

\section{Saran}

1. Untuk meningkatkan hasil belajar, para guru hendaknya menggunakan tidak menggunakan metode semata tetapi juga bisa menggunakan permaian sebagai menarik minat siswa pada pembelajaran agar dapat meningkatkan hasil belajar sosiologi di SMAN 1 Langsa.

2. Perlu dilakukan penelitian lebih lanjut mengenai penggunaan permainan makah-makah pada materi yang berbeda sehingga dapat menjadi bahan masukan dan penyempurnaan penelitian ini.

\section{DAFTAR PUSTAKA}

“Aceh Serambi Mekah”, Diunduh pada tanggal 13 Maret 2016 dari (http://achehlibrary.com).

Aunurrahman. 2016. Belajar dan Pembelajaran. Bandung : Alfabeta.

Depdiknas.2003. Kurikulum 2004 Standar Kompetensi Mata Pelajaran Sosiologi SMA/MA. Jakarta.

Djamarah, Syaiful Bahri. 2104. Pola Asuh Orangtua dan Komunikasi Dalam Keluarga. Jakarta: Rineka Cipta

Elisabeth.b. Hurlock,. 1992. Psikologi Perkembangan Anak Jilid 2. Jakarta Erlangga 
Sardiman. 2009. Interaksi dan Motivasi Belajar Mengajar. Jakarta: PT. Rajawali. Pers.

Sufi. 2004. Keanekaragaman Suku dan Budaya di Aceh. Banda Aceh: Balai Kajian Sejarah dan Nilai Tradisional Banda Aceh Bekerja Sama Dengan Bandan Perpustakaan Provinsi Nanggroe Aceh Darussalam.

Sugiyono, 2016. Metodologi Penelitian Pendidikan Pendekatan Kuantitatif, Kualitatif dan $R \& D$. Bandung : Alfabeta.

Suprijono, Agus. 2013. Cooperative Learning Teori dan Aplikasi PAIKEM. Yogyakarta: Pustaka Pelajar 